College of William \& Mary Law School William \& Mary Law School Scholarship Repository

1979

\title{
Rites of Passage: Race, the Supreme Court, and the Constitution
}

William W. Van Alstyne

William \& Mary Law School

\section{Repository Citation}

Van Alstyne, William W., "Rites of Passage: Race, the Supreme Court, and the Constitution" (1979). Faculty Publications. 726.

https://scholarship.law.wm.edu/facpubs/726

Copyright c 1979 by the authors. This article is brought to you by the William \& Mary Law School Scholarship Repository. https://scholarship.law.wm.edu/facpubs 


\title{
Rites of Passage: Race, the Supreme Court, and the Constitution
}

\author{
William Van Alstyne ${ }_{\dagger}^{\dagger}$
}

From $1619^{1}$ to 1979 , the regulation and allocation of rights according to race has been among the most troubling uses of government in the United States. Entrenched in the Constitution of $1787^{2}$ and sustained by the Supreme Court in $1857,{ }^{3}$ the original uses of race proved to be nationally intolerable and were overthrown by the Civil War. The enormous alterations resulting from that War were partly memorialized in three amendments to the Constitution, between 1866 and 1870. These effectively overrode the still extant provisions from the "accommodations" of 1787 . They also provided the new text, which, from that time to this time, has fixed the ground of controversy respecting regulation by race. They are, of course, the thirteenth, fourteenth, and fifteenth amendments.

The first of these amendments prohibits all forms of involuntary servitude and allows Congress an ample power to police that ban through federal law. ${ }^{4}$ The fourteenth amendment is far more lengthy than the thirteenth, but in its most essential parts it establishes a constitutional definition of citizenship and forbids the states to abridge the incidents of national citizenship. It also forbids the states to deny equal protection to any person or to deprive any

$\dagger$ William R. Perkins Professor of Law, Duke University.

1619 is a late, inaccurate date, symbolically selected more because it marks the original landing of slaves at Jamestown, Virginia, than because it marks the first uses of race in America.

2 The framers carefully avoided using terms such as "slavery" and "race." Nonetheless, several provisions in the original Constitution manifestly grant recognition to the legal existence of slavery. E.g., U.S. CoNST. art. I, \& 2, cl. 3 (defining state populations, for purposes of apportionment of Representatives and direct taxes, as the sum of "the whole number of free Persons" and, "excluding Indians not taxed, three-fifths of all other Persons"); id. § 9, cl. 1 (forbidding Congress to prohibit "Importation of such Persons" as states choose to admit before 1808); $i d$. art. IV, $\S 2, \mathrm{cl} .3$ (forbidding state law from altering the status of any escaping "Person held to Service or Labour" in another state, and requiring delivery of such persons on demand); id. art. V (forbidding amendment, before 1808, of the Senate representation formula or the importation-of-persons clause).

${ }^{3}$ Dred Scott v. Sandford, 60 U.S. (19 How.) 393 (1857).

- SEcrion 1. Neither slavery nor involuntary servitude, except as a punishment for crime whereof the party shall have been duly convicted, shall exist within the United States, or any place subject to their jurisdiction. tion.

Secrion 2. Congress shall have power to enforce this article by appropriate legisla-

U.S. Const. amend. XIII. 
person of life, liberty, or property "without due process of law," and it vests in Congress an ample power to enforce these protections. ${ }^{5}$ The last-the fifteenth amendment-is more limited: it more explicitly protects the right to vote from abridgment "on account of race, color, or previous condition of servitude," again concluding with a section vesting in Congress ample power to vindicate that protection. ${ }^{3}$ The extent to which these three amendments enacted a color-blind restriction on the recurring temptation of government to regulate or allocate by race, however, was a question plainly not settled between 1866 and 1870 . It remains unsettled even now.

At one level, the sheer stamina of the question, despite the passage of a century's opportunity for its resolution, is not surprising. The texts of these amendments are sufficiently unspecific that, even in the aggregate, with their obvious connections with one another and with the Civil War, they compel no single answer. Similarly, the welter of accompanying legislative history is amenable to more than one reasonable perspective. That people should disagree, and that mutually earnest scholars do disagree, is, therefore, rather to be expected even at this very late date. ${ }^{7}$ The materials of enlight-

5 Section 1. All persons born or naturalized in the United States, and subject to the jurisdiction thereof, are citizens of the United States and of the State wherein they reside. No State shall make or enforce any law which shall abridge the privileges or immunities of citizens of the United States; nor shall any State deprive any person of life, liberty, or property, without due process of law; nor deny to any person within its jurisdiction the equal protection of the laws.

SECTION 5. The Congress shall have power to enforce, by appropriate legislation, the provisions of this article.

Id. amend. XIV.

- SEction 1. The right of citizens of the United States to vote shall not be denied or abridged by the United States or by any State on account of race, color, or previous condition of servitude.

SECTiON 2. The Congress shall have power to enforce this article by appropriate legislation.

Id. amend. XV.

7 See, e.g., R. Berger, Government gy Judiciary (1977); 2 W. Crosskey, Politics and the Constitution IN the History of the Untted States 1083-1118 (1953); H. Flack, The Adoption of the Fourteenth Amendment (1908); W. Giliette, The Right To Vote (1965); R. HaRris, The Quest for Equality (1960); J. James, The Framing of the Fourteenth Amendment (1956); J. Mathews, Legislative and Judicial History of the Fifteenth Amendment (1909); H. Meyer, The History and Meaning of the Fourteenth AMEndment (1977); J. TenBrogk, Equal Under Law (1965) (originally published as The Antislavery Origins of the Fourteenth Amendment (1951)); Avins, The Equal "Protection" of the Laws: The Original Understanding, 12 N.Y.L.F. 385 (1966); Bickel, The Original Understanding and the Segregation Decision, 69 HARv. L. REv. 1 (1955); Frank \& Munro, The Original Understanding of "Equal Protection of the Laws," 50 CoLum. L. REv. 131 (1950); Graham, The Early Anti-Slavery Backgrounds of the Fourteenth Amendment, 1950 WIs. L. REv. 479; Graham, Our "Declaratory" Fourteenth Amendment, 7 Stan. L. REv. 3 (1954); 
ened constitutional interpretation permit us, I think, to treat the Constitution as repudiating the propriety of regulating people by race or allocating among people by race, but they do not compel that conclusion. It is oddly a matter of what we might wish to make of it. It has always been this way.

What is less explicable, at least to nonlawyers, is that after a century of periodic judicial review there is still no formal resolution of the question. And this seems very odd. Laws regulating on the basis of race were in existence before the Civil War amendments were adopted; many were judicially examined in litigation prompted by the passage of these amendments. Other laws regulating on the basis of race were enacted after ratification of all three amendments, and still others are tenaciously put forward today; many of these have similarly been tested in the Supreme Court. ${ }^{8}$ One would surely suppose that, for judicial purposes at least, so old and so obvious an issue would long ago have been settled to provide us with some steady impression of the extent to which government may regulate or allocate by race. But it is not so.

Rather, the Supreme Court has itself gone through two quite distinct rites of passage. Now-in the "minority contractors" case, ${ }^{9}$

Van Alstyne, The Fourteenth Amendment, the "Right" to Vote, and the Understanding of the Thirty-Ninth Congress, 1965 Sup. Cr. REv. 33.

8 For Supreme Court cases considering laws regulating by race in the generation after the Civil War, see, for example, Plessy v. Ferguson, 163 U.S. 537 (1896); Pace v. Alabama, 106 U.S. 583 (1883); Strauder v. West Virginia, 100 U.S. 303 (1880). For a modern example of a law dictating race-based allocation, see Fullilove v. Kreps, 584 F.2d 600 (2d Cir. 1978), cert. granted, 99 S. Ct. 2403 (1979).

- Fullilove v. Kreps, 584 F.2d 600 (2d Cir. 1978), cert. granted, 99 S. Ct. 2403 (1979). It involves an equal protection challenge to section 103(f)(2) of the Public Works Employment Act of 1977, 42 U.S.C. $\$ 6705(f)$ (2) (Supp. I 1977). This casually added provision-that is, added and hardly discussed on the floor of the House, and not even considered in committee debates-provides that at least $10 \%$ of federal public works grants under the Act be expended for "minority business enterprises." Such enterprises are defined as businesses owned principally by "Negroes, Spanish-speaking, Oriental, Indians, Eskimos, and Aleut." For further discussion of this type of plan, see text at note 91 infra.

The constitutional question should not be influenced by the Court's recent decision (mis)construing Title VII of the Civil Rights Act of 1964, 42 U.S.C. $\$ \$ 2000 \mathrm{e}$ to $2000 \mathrm{e}-17$ (1976), as not prohibiting a one-for-one minority quota for admissions to an on-the-job training program. United Steelworkers v. Weber, $99 \mathrm{~S}$. Ct. 2721 (1979). Indeed, Justice Brennan declared for the Court: "We emphasize at the outset the narrowness of our inquiry. . . . [T]his case does not present an alleged violation of the Equal Protection Clause of the Constitution. . . The only question before us is the narrow statutory issue . . . "Id. at 2726.

Fullilove will, however, revive and challenge the four-one-four division of the Court in its review of a $16 \%$ racial minority minimum set-aside program at a state university medical school, under racially separate and unequal standards of admissions. Regents of the Univ. of Cal. v. Bakke, 438 U.S. 265 (1978). There, four Justices (Brennan, White, Marshall \& Black- 
before the Court this fall-it is considering still another. And what many had misled themselves into supposing had been the clear, best resolution of this matter during the last generation is on the edge of turning over once again.

In the past, the consequences of admitting race-based laws as a proper constitutional foundation for regulating and allocating have been overwhelmingly dismal. Race-based laws have so generally tended to yield by-products and side effects so vastly more divisive and wretched than the benefits that were supposed to be forthcoming, moreover, that a Court originally not predisposed to veto racial experiments subsequently reversed itself-despite the popular anger and resentment that were certain to follow. Now, however, having virtually captured the public morality after twenty-five years of leadership on this question, the Supreme Court is being importuned to let loose of it once again.

On the confident assurance that there are still important uses for race-based laws in the more perfect ordering of this society, the Court is invited into yet another rite of passage. The suggestion, which is not new but which was always a feature of even the oldest race-based laws, is that it is not the regulating or allocating by race that is wrong or too risky per se; it is, rather, who is thus regulated, what is thus allocated, what motivates the arrangement, and what time frame should be followed.

My own view of the matter is that the Court is being asked to permit not racial rectification (in reviving the licitness of race as an explicit device of government) but racial repetition. ${ }^{10} \mathrm{I}$ think it likely, moreover, that if the Court yields once again to the Lorelei, racism, racial spoils systems, racial competition, and racial odium will be fixtures of government in the United States even into the twenty-first century. My reasons for feeling this way are not original. Generally, moreover, they are not shared by the majority of

mun) found the plan compatible with the fourteenth amendment; four (Burger, Stewart, Rehnquist \& Stevens) declined to reach the question, finding the plan prohibited by 42 U.S.C. $\$ 2000 \mathrm{~d}$ (1976); the ninth Justice (Powell) concluded that the particular plan was not compatible with the fourteenth amendment. For discussions of the uncertainties arising from this case, see $A$ Symposium: Regents of the University of California v. Bakke, 67 CALIF. L. REv. 1 (1979); Tribe, Perspectives on Bakke: Equal Protection, Procedural Fairness, or Structural Justice?, 92 Harv. L. Rev. 864 (1979); Van Alstyne, A Preliminary Report on the Bakke Case, 64 A.A.U.P. Bull. 286 (1978); Controversy: More on the Bakke Decision, 65 Academe 49 (1979).

10 The point in using the term racial "repetition" is to stress that once the use of race becomes legitimate again, we shall repeat all of the problems that divided us before: solidarity collapses, consensus with respect to the impropriety of measuring by race dissolves, race becomes important once more, and all are diminished by the experience. 
constitutional law professors who have written on this subject." Even so, the sense of anxiety that what is now adrift before the Supreme Court deserves some added thought before it passes into history provides the occasion for these notes.

\section{Earlier Rites of Passage}

The lesson of the great decisions of the Supreme Court and the lesson of contemporary history have been the same for at least a generation: discrimination on the basis of race is illegal, immoral, unconstitutional, inherently wrong, and destructive of democratic society.

Alexander M. Bickel ${ }^{12}$

This has been the lesson of "the great decisions" and of contemporary history. It is not the "holding" of a particular case; it is, as

"The body of literature in this area is extensive. See, e.g., B. BITTKER, THE CASE POR Black Reparations (1973); R. Dworkin, Reverse Discrimination, in Taking Rights Seriously 223 (1977); T. Eastland \& W. Bennett, Counting by Race (1979); N. Glazkr, Afrirmative Discrimination (1975); Reverse Discrimination (B. Gross ed. 1977); R. O'NeIt, Discriminating Against Discrimination (1975); Baldwin \& Nagan, Board of Regents v. Bakke: The AllAmerican Dilemma Revisited, 30 U. FLA. L. REv. 843 (1978); Bell, Bakke, Minority Admissions, and the Usual Price of Racial Remedies, 67 CAur. L. Rev. 3 (1979); Blasi, Bakke as Precedent: Does Mr. Justice Powell Have a Theory?, 67 Catrr. L. Rev. 21 (1979); Brest, The Supreme Court, 1975 Term-Foreword: In Defense of the Antidiscrimination Principle, 90 Harv. L. Rev. 1, 16-22 (1976); Dixon, Bakke: A Constitutional Analysis, 67 CaLr. L. Rev. 69 (1979); Ely, The Constitutionality of Reverse Racial Discrimination, 41 U. CH. L. Rev. 723 (1974); Fiss, Groups and the Equal Protection Clause, 5 Puwosophy \& PuB. Arr. 107 (1976); Greenawalt, Judicial Scrutiny of "Benign" Racial Preference in Law School Admissions, 75 Colum. L. Rev. 559 (1975); Greenawalt, The Unresolved Problems of Reverse Discrimination, 67 Callp. L. Rev. 87 (1979); Hastie, Affirmative Action in Vindicating Civil Rights, 1975 U. Iut. L.F. 502; Kaplan, Equal Justice in an Unequal World: Equality for the Negro-The Problem of Special Treatment, 61 Nw. U.L. REv. 363 (1966); Karst, The Supreme Court, 1976 Term-Foreword: Equal Citizenship Under the Fourteenth Amendment, 91 HARv. L. REv. 1 (1977); Karst \& Horowitz, Affirmative Action and Equal Protection, 60 VA. L. Rev. 955 (1974); Morris, Equal Protection, Affirmative Action and Racial Preferences in Law Admissions: DeFunis v. Odegaard, 49 WASH. L. Rev. 1 (1973); Nagel, Equal Treatment and Compensatory Discrimination, 2 Phiоosopнy \& PuB. Afr. 348 (1973); O'Neil, Bakke in Balance: Some Preliminary Thoughts, 67 CaLtr. L. REv. 143 (1979); O'Neil, Preferential Admissions: Equalizing the Access of Minority Groups to Higher Education, 80 YALE L.J. 699 (1971); O'Neil, Racial Preference and Higher Education: The Larger Context, 60 VA. L. REv. 925 (1974); Posner, The Bakke Case and the Future of "Affirmative Action," 67 Calur. L. Rev. 171 (1979); Posner, The DeFunis Case and the Constitutionality of Preferential Treatment of Racial Minorities, 1974 Sup. CT. REv. 1; Ravenell, DeFunis and Bakke . . . The Voice Not Heard, 21 How. L.J. 128 (1978); Sandalow, Racial Preferences in Higher Education: Political Responsibility and the Judicial Role, 42 U. CH. L. Rev. 653 (1975); Sedler, Racial Preference, Reality and the Constitution: Bakke v. Regents of the University of California, 17 SANTA Clara L. Rev. 329 (1977); Seeburger, A Heuristic Argument Against Preferential Admissions, 39 U. PITT. L. REv. 285 (1977); Tribe, supra note 9.

12 A. Bickel, The MoraltTy of Consent 133 (1975). 
Alexander Bickel said, the lesson of the great decisions, a lesson it required nearly eighty years of temporizing for the Supreme Court itself to absorb.

\section{A. The Original Interpretation}

The first passage for the Court came with the immediate adjudication of race-related cases on the heels of the Civil War amendments. With the exception of a few notable cases striking down the most egregious race regulations, ${ }^{13}$ the Supreme Court adopted a wholly tolerant and deferential rendering of all three amendments, imputing to them only the most modest consequences. ${ }^{14}$ Federal statutes flatly forbidding racial discrimination by commercial enterprises were held to be excessive, as acts of an unwarranted colorblind zeal. The thirteenth amendment would not sustain them, because mere commercial refusals to deal with people on racial grounds were regarded by the Court as too far removed from involuntary servitude. The fourteenth amendment provided no basis for such legislation, moreover, because that amendment reached only the government's own denials of equal protection, not those of private, commercial parties. The fifteenth amendment was not useful, of course, as it dealt solely with voting. The cases so disposing of this matter, decided by the Supreme Court in 1883, were ironically entitled The Civil Rights Cases. ${ }^{15}$

When regulation by race was the government's own, rather than the practice of private parties, the Court's decisions were nearly as tolerant of legislative discretion as they had been of commercial discrimination in The Civil Rights Cases. Allocation by race was not per se forbidden by the Constitution, the Court held, as the consideration of race might be thought by many reasonable persons as sometimes germane to a variety of important social concerns. Thus, the question was not whether political bodies regulated on the basis of race; it was the different question whether the particular regula-

${ }^{13}$ E.g., Strauder v. West Virginia, 100 U.S. 303 (1880) (exclusion of Negroes from juries unconstitutional). Cf. Virginia v. Rives, 100 U.S. 313, 319 (1880) (dictum) ("denial of [equal protection] rights, or an inability to enforce them, resulting from the Constitution or laws of the State" allows removal of case from state to federal court); Ex parte Virginia, 100 U.S. 339 (1880) (denying writ of habeas corpus to judge who was under indictment and in custody for excluding blacks from juries).

" E.g., The Slaughter-House Cases, 83 U.S. (16 Wall.) 36 (1873) (fourteenth amendment privileges and immunities clause reduced to a constitutional redundance).

is 109 U.S. 3 (1883). See also United States v. Harris, 106 U.S. 629 (1883) (section 5 of the fourteenth amendment, creating enforcement powers of Congress, very narrowly construed); United States v. Cruikshank, 92 U.S. 542 (1876) (same). 
tion by race was constitutionally "reasonable."

The Court's view-that the laws would be sustained if "reasonable"-genuflected to the wisdom of legislative bodies to sort out good from bad uses of race; the Court quite readily acquiesced in disclaimers that the fourteenth amendment meant no across-the-broad foreclosure of such experiments. Regulation by race was not condemnable or censurable as such; only unfair, onesided, or unevenhanded race regulation or allocation was forbidden. If individuals could be equally protected, albeit racially regulated, then nothing in the command or ethos of the fourteenth amendment was deemed to deny the use of racial classification to the body of American politics.

This view of the matter steadily developed between 1873 and the twilight of the 19 th century. It was cemented in 1896 in the "separate-but-equal" decision of Plessy $v$. Ferguson. ${ }^{16}$ The decision upheld a state law requiring separate passenger cars for white and for black riders: ${ }^{17}$ neither was worse off than the other in the quality of accommodations to be furnished to each; neither was more or less protected than the other (rather, each was equally protected) by the racial regulation a legislative body deemed reasonable in the public interest.

There was but one dissent that took a less measured view and would have imposed upon the fourteenth amendment a more categorical imperative. Less flexible than others on the Supreme Court at the time, Justice Harlan was prepared to read into the Civil War amendments what was, to be sure, neither explicitly provided by their terms nor compelled by their compromised legislative history. Proceeding from a more basic premise than that either of these considerations necessarily controlled the matter, Harlan put his finger on the lessons of his own contemporary history. Prior to the Civil War amendments, race was the basis on which status had been determined, worth assigned, entitlements settled, and legal rights measured. It had been iniquitous from the very beginning, and it subsequently proved to be a disaster for the entire country. He believed the enactment of the Civil War amendments should therefore be construed by the Court as altogether disallowing it. Govern-

16 163 U.S. 537 (1896).

17 In Louisville, N.O. \& T. Ry. v. Mississippi, 133 U.S. 587 (1890), a similar statute survived an attack under the commerce clause, U.S. Const. art I, $\$ 8, \mathrm{cl} .3$; the Court made no reference to the equal protection clause.

The Plessy majority relied in part on a pre-Civil War Massachusetts school segregation case, litigated under a portion of the Massachusetts Constitution bearing some resemblance to the fourteenth amendment's equal protection clause. Roberts v. City of Boston, 59 Mass.

(5 Cush.) 198 (1850). 
ment could not determine worth, assign entitlements, or measure legal rights by race at all:

The law regards man as man, and takes no account of his surroundings or of his color when his civil rights as guaranteed by the supreme law of the land are involved. . . .

... The destinies of the two races, in this country, are indissolubly linked together, and the interests of both require that the common government of all shall not permit the seeds of race hate to be planted under the sanction of law. . . .

The sure guarantee of the peace and security of each race is the clear, distinct, unconditional recognition by our governments, National and State, of every right that inheres in civil freedom, and of the equality before the law of all citizens of the United States without regard to race. ${ }^{18}$

The point of emphasis here is fundamental. It is not that when race is used, all persons identified to each race must be as well regarded as all persons identified to some other race. ${ }^{19}$ The thing condemned is not that members of each race must be "equally" protected under laws distinguishing them by their race, nor that they are assigned entitlements unequally on the basis of race. The thing condemned, rather, is the assignment of entitlements by race. It is the impropriety of the basis of assignment, not the modicum thus assigned, that constitutes the government's offense:

These notable additions to the fundamental law [the thirteenth, fourteenth, and fifteenth amendments] were welcomed by the friends of liberty throughout the world. They removed the race line from our governmental systems. ${ }^{20}$

The Harlan opinion passed into history at the time, an artifact of mere dissent, discredited by the dominant view that the fourteenth amendment had not withdrawn from legislative bodies a political license to regulate by race. The outcome of the case was taken quite seriously, moreover, as legislatures enacted an ever-

${ }^{18}$ Plessy v. Ferguson, 163 U.S. 537, 559-60 (1896) (Harlan, J., dissenting) (emphasis added). Harlan had similarly dissented in The Civil Rights Cases, 109 U.S. 3, $24-62$ (1883) (Harlan, J., dissenting). See also Berea College v. Kentucky, 211 U.S. 45, 67-69 (1908) (Harlan, J., dissenting). But see Cumming v. Richmond County Bd, of Educ., 175 U.S. 528 (1899) (Harlan, J.). See generally Westin, John Marshall Harlan and the Constitutional Rights of Negroes: The Transformation of a Southerner, 66 YaLE L.J. 637 (1957).

19 See O'Fallon, Adjudication and Contested Concepts: The Case of Equal Protection, 54 N.Y.U.L. REv. 19, 34-38 (1979),

20 Plessy v. Ferguson, 163 U.S. 537, 555 (1896) (Harlan, J., dissenting) (emphasis added). 
enlarging sprawl of race-based laws. ${ }^{21}$ Indeed, a half-century later, the dominant legislative response to Brown v. Board of Education ${ }^{22}$ was one of fury, precisely on this account. For however the Court might phrase the apologetics of that decision, ${ }^{23}$ the message as it appeared from the outside was that what was not previously understood to be unconstitutional was now accused of being unconstitutional after all: the use of race to allocate-albeit equally-those facilities deemed most appropriate for persons of that race.

\section{B. The Second Rite of Passage}

In the swift consecutive series of per curiam decisions issued by the Supreme Court during the two years following Brown, the Court made no further use whatever-indeed, it made no inquiry-as to whether the particular race regulation disadvantaged some more than others. Neither did it ask whether the law stigmatized some more than others, or whether the law was enacted by whites and opposed by blacks, enacted by consent of some of each and opposed by many of each, or whatever. ${ }^{24}$ Rather, that line of per curiam decisions appeared more completely to enact Harlan's view that the Civil War amendments altogether "removed the race line from our governmental systems."

Between 1955 and 1976, moreover, virtually every other racerelated decision by the Supreme Court appeared to convey this same message. To the reasonably discerning, this appeared true even in instances involving highly controversial judicial decrees that

21 See generally C. Woodward, The Strange Carker of Jim Crow (3d ed. 1974). See also Westin, supra note 18, at 706 \& n.324.

22347 U.S. 483 (1954).

23 See D. Bell, Race, Racism and Amgrican Law 452 (1973); Wechsler, Toward Neutral Principles of Constitutional Law, 73 Harv. L. REv. 1, 31-33 (1959).

24 The particular case overruling Plessy (sub silentio) was itself without an explanatory opinion, Gayle v. Browder, 352 U.S. 903 (1956), aff'g per curiam 142 F. Supp. 707 (M.D. Ala. 1956). One district court interpreted certain dicta in Brown as not disallowing per se governmentally directed, racially separated schools, Stell v. Savannah-Chatham County Bd. of Educ., 220 F. Supp. 667, 677-78 (S.D. Ga. 1963), but was speedily rebuffed on appeal, 333 F.2d 55, 61 (5th Cir.), cert. denied, 379 U.S. 933 (1964). Alternative interpretations of Brown are, of course, numerous. For one listing, see H. HorowtTz \& K. KArST, LAw, LAwYRrS and Social Change 203 (1969). For additional post-Brown decisions summarily dispatching other segregation laws, see, for example, State Athletic Comm'n v. Dorsey, 359 U.S. 533 (1959), aff'g per curiam 168 F. Supp. 149 (E.D. La. 1958) (athletic contests); Holmes v. City of Atlanta, 350 U.S. 879 (1955), vacating per curiam 223 F.2d 93 (5th Cir. 1955) (municipal golf courses); Mayor of Baltimore City v. Dawson, 350 U.S. 877 (1955), aff'g per curiam 220 F.2d 386 (4th Cir. 1955) (public beaches and bathhouses); cases cited in W. LockHART, Y. Kamisar, \& J. Choper, Cases and Materials on Constitutional Rights and Liberties 840 nn.a \& b (3d ed. 1970). 
paired racially identifiable schools, redrafted attendance lines, or mandated busing. In each instance, the fulcrum of judicial leverage was an existing governmental race line, which the particular judicial order sought to remove. ${ }^{25}$ The object was thus to disestablish particular, existing uses of race, not to establish new ones. Indeed, decrees that would subsequently presume to require race-conscious decisions for any other purpose, for example, to maintain "proportions" or "balances" by race designation, were swiftly reversed. ${ }^{28}$

This second rite of passage was accompanied by consistent developments in the 1960s in the Supreme Court and then, encouragingly, in Congress and the executive branch as well. For the Court's part, long dormant Reconstruction statutes were revived and given a reinvigorated and uniformly race-blind application. An early act of Congress had provided that all citizens shall have "the same" right as white citizens to acquire and to hold real and personal property. ${ }^{27}$ It was applied to disallow race-based refusals to deal in real estate, even in the private sector. ${ }^{28} \mathrm{~A}$ related Reconstruction act provided that all persons shall have "the same" right as white citizens to make contracts. ${ }^{29}$ It was similarly read to disallow race-based refusals to contract..$^{30}$ In 1976 , when a commercial employer treated an employee worse than another because of his race (this time the less favored employee was white and the more favored black), the Court held to the same view: "[T]he Act was meant, by its broad terms, to proscribe discrimination in the making or enforcement of contracts against, or in favor of, any race."31

Similarly, in adopting the omnibus Civil Rights Act of 1964, Congress appeared to regard the matter likewise: the race line was to be removed altogether. Title VI of that Act, applicable to all

${ }^{25}$ See, e.g., Swann v. Charlotte-Mecklenburg Bd. of Educ., 402 U.S. 1 (1971). See also 'Dayton Bd. of Educ. v. Brinkman, 99 S. Ct. 2971 (1979); Columbus Bd. of Educ. v. Penick, 99 S. Ct. 2941 (1979).

${ }^{26}$ E.g., Pasadena City Bd. of Educ. v. Spangler, 427 U.S. 424 (1976). See also Dayton Bd. of Educ. v. Brinkman, 433 U.S. 406 (1977); Milliken v. Bradley, 418 U.S. 717 (1974); Keyes v. School Dist. No. 1, 413 U.S. 189 (1973).

${ }_{27}$ Act of Apr. 9, 1866, ch. 31, $\$ 1,14$ Stat. 27 (current version at 42 U.S.C. $\$ 1982$ (1976)).

28 Jones v. Alfred H. Mayer Co., 392 U.S. 409 (1968). (1976)).

29 Act of May 31, 1870, ch. 114, § 16, 16 Stat. 144 (current version at 42 U.S.C. $\$ 1981$

${ }^{30}$ Runyon v. McCrary, 427 U.S. 160 (1976); Johnson v. Railway Express Agency, 421 U.S. 454, 459-60 (1975) (dictum).

3t McDonald v. Santa Fe Trail Transp. Co., 427 U.S. 273, 295 (1976) (emphasis added). But cf. id. at $280 \mathrm{n.8}$ ("Santa Fe disclaims that the actions challenged here were any part of an affirmative action program ... and we emphasize that we do not consider here the permissibility of such a program, whether judicially required or otherwise prompted."). 
programs receiving federal financial assistance, states: "No person in the United States shall, on the ground of race, color, or national origin, be excluded from participation in, be denied the benefits of, or be subjected to discrimination under any program or activity receiving Federal financial assistance." 32 And Title VII, applicable to all large-scale employers, provides: ployer-

It shall be an unlawful employment practice for an em-

(1) to fail or refuse to hire or to discharge any individual, or otherwise to discriminate against any individual with respect to his compensation, terms, conditions, or privileges of employment, because of such individual's race, color, religion, sex, or national origin . . . . ${ }^{33}$

Addressing the meaning of this provision in 1971, in the first case to come before it for review, the Court, in a unanimous opinion by Chief Justice Burger, said that "[d]iscriminatory preference for any group, minority or majority, is precisely and only what Congress has proscribed." 34

Conformably, the executive branch of the national government appeared to understand matters in the same fashion. For in cutting and revising an Executive Order that regulated enterprises doing business with the federal government, the President framed the Order itself precisely and exclusively in terms of strict nondiscrimination. Federal contractors were advised to review their practices to determine whether, if even by neglect, racial discrimination figured in their businesses; if it did, the contractors would have to take affirmative action-to eliminate that racial discrimination and to insure that no racial favoritism was built into their operations. Thus, the revised Executive Order required the insertion of the following provision in most government contracts:

32 Title VI of the Civil Rights Act of 1964, $\S 601,42$ U.S.C. $\S 2000$ d (1976) (emphasis added). Compare the several differing interpretations provided in Regents of the Univ. of Cal. v. Bakke, 438 U.S. 265 (1978).

${ }^{33}$ Title VII of the Civil Rights Act of 1964, $\$ 703(a)(1), 42$ U.S.C. $\$ 2000 \mathrm{e}-2(\mathrm{a})(1)$ (1976) (emphasis added). This, of course, is simply what Congress said. Compare United Steelworkers v. Weber, 99 S. Ct. 2721, 2724-30 (1979) (Brennan, J.) with id. at 2734-35 (Burger, C.J., dissenting) and id. at 2736-53 (Rehnquist, J., dissenting).

34 Griggs v. Duke Power Co., 401 U.S. 424, 431 (1971) (emphasis added). And reiterating that view in 1976, the Court declared: "We . . . hold today that Title VII prohibits racial discrimination against the white petitioners in this case upon the same standards as would be applicable were they Negroes . . ." McDonald v. Santa Fe Trail Transp. Co., 427 U.S. 273, 280 (1976) (emphasis added). But see United Steelworkers v. Weber, 99 S. Ct. 2721 (1979). 
The contractor will not discriminate against any employee or applicant for employment because of race, color, religion, sex, or national origin. The contractor will take affirmative action to ensure that applicants are employed, and that employees are treated during employment without regard to their race, color, religion, sex or national origin. ${ }^{35}$

In light of these several developments, it should have come as no surprise that in 1974, in the first case that came before the Supreme Court involving race lines deliberately drawn to place a racial disadvantage on white applicants-drawn out of fear that if no such disadvantage were imposed upon them, then fewer nonwhite individuals might be admitted than the faculty of a state university preferred to have-the one Justice of the Supreme Court who addressed the merits of the case said this: ,

A DeFunis who is white is entitled to no advantage by reason of that fact; nor is he subject to any disability, no matter what his race or color. . . .

. . . The Equal Protection Clause commands the elimination of racial barriers, not their creation in order to satisfy our theory as to how society ought to be organized. . . .

. . . So far as race is concerned, any state-sponsored preference to one race over another . . . is in my view "invidious" and violative of the Equal Protection Clause. ${ }^{36}$

Justice Douglas then directly addressed the law school's contention that the race-preferential admission of some students would be a salutary way of producing a larger complement of such racially identifiable professionals more likely to practice in racially identifiable communities. He rejected the propriety of the very idea underlying that contention: "The purpose of the University of Washington cannot be to produce black lawyers for blacks, Polish lawyers for Poles, Jewish lawyers for Jews, Irish lawyers for Irish. . . . That is the point at the heart of all our school desegregation cases." ${ }^{\prime 37}$ And neither was Justice Douglas persuaded that the deliberate selection of

${ }^{35}$ Exec. Order No. 11246, $\$$ 202, 3 C.F.R. 339, 340-41 (1964-1965 Compilation), as amended by Exec. Order No. 11375, 3 C.F.R. 684, 685-86 (1966-1970 Compilation), reprinted in 42 U.S.C. $\$ 2000 \mathrm{e}$, at 1233 (1976) (emphasis added). This, too, is simply what the President said. Compare id. with 42 Op. Att'y Gen. 405 (1969).

* DeFunis v. Odegaard, 416 U.S. 312, 337, 342, 343-44 (1974) (Douglas, J., dissenting) (emphasis added).

${ }^{37}$ Id. at $342-43$ (Douglas, J., dissenting). 
students by race, to produce a given cohort of racially identified students known to have been admitted with less excellent qualifications than the balance of the students, was by any means the gesture of generosity it purported to be. A segregated admissions process that seeks certain minimum proportions of racial cohorts, he said, "creates suggestions of stigma and caste no less than a segregated classroom, and in the end it may produce that result despite its contrary intentions." 38

The refusal to permit rationing of opportunity according to the fortuity of racial proportion was not a novelty invented by Justice Douglas. In 1949, the Supreme Court had reviewed a case arising in

38 Id. at 343 (Douglas, J., dissenting). See also Regents of the Univ. of Cal. v. Bakke, 438 U.S. 265, 298 (1978) (Powell, J.): "[P]referential programs may only reinforce common stereotypes holding that certain groups are unable to achieve success without special protection based on a factor having no relationship to individual worth."

Not all race-specific "preferential" government-utilized plans involve separate and lower standards of selection. Some (as illustrated by the Bakke case itself) plainly do. And these plans unquestionably impose a racial stigma on those who benefit by them, for reasons that cannot be avoided by the beneficiaries. This may be a cost that others would regard as utterly trivial when weighed against the benefits and overall good of such arrangements. Others may also say that this is a matter they do not wish to judge - that whether there is a stigmatizing effect and whether it renders such a plan undesirable is emphatically not for them to say. Such persons might feel that it is, rather, a matter to be determined by those eligible for the plan-and that these persons will show, by their participation, that they overwhelmingly regard the very material benefits, with whatever stigma may attach, to be vastly superior to the status quo ante. But the stigma is spread to others identified only by race, who are helpless to avoid it. Indeed, it will have been the government itself that fastened the stigma upon them, a new badge of implied inferiority, assigned as an incident of governmental noblesse oblige.

Explicit in state, local, or federal plans using separate and lower standards by race is a statement by government that certain persons identified by race are in fact being placed in positions they may be presumed not likely to hold but for their race (because they are presumed to be unable to meet standards the government itself otherwise requires to be met). The message from government is written very large when these plans proliferate: a double (and softer) standard for admission, a double (and softer) standard for hiring, a double (and softer) standard for promotion, a double (and softer) standard for competitive bidding, and so on. Without question, this is a systematic racial tagging by government-a communication to others that the race of the individual they deal with bespeaks a race-related probability, created solely by the government itself, of lesser qualification than others holding equivalent positions.

With respect to some such persons, the supposition will be true, according to the government's own usual standards of "qualifications." With respect to others of the same race, the proposition will be false; but outsiders dealing with them will not know it is false unless "affirmative action" beneficiaries are specially to be labelled as such-surely an unthinkable practice-and will, solely because of the government's own practice, be encouraged to subject them to a racial stereotype. In brief, the government's entrenched practices impose a label of inferior excellence that the government itself declares to be true of some persons; simultaneously, the government fastens a racial stereotype on all other persons of the same race holding similar positions, irrespective of their actual excellence. Whether this is unconstitutional remains to be seen. That it is not "stigmatizing" seems implausible. 
California where public policy had already forbidden racial discrimination in private employment. ${ }^{39} \mathrm{~A}$ racial group nonetheless brought economic pressure to bear upon an employer to disregard that policy and to hire employees "not on fitness for the work nor on an equal right of all, regardless of race, to compete in an open market, but, rather, on membership in a particular race." 40 The state supreme court granted an injunction to forbid picketing meant to induce racial hiring in proportion to the racial identification of customers. The court had observed: "If petitioners were upheld in their demand then other races, white, yellow, brown and red, would have equal rights to demand discriminatory hiring on a racial basis." 41 But the state supreme court said "it was just such a situation-an arbitrary discrimination upon the basis of race and color alone, rather than a choice based solely upon individual qualification for the work to be done-which we condemned"42 in disallowing racial discrimination by employers in the first place. The Supreme Court unanimously affirmed the state court decision. ${ }^{43}$

Even when the sole use of race by government was to suggest that race is at least an important political datum-the government itself not presuming to say of what kind of significance-the Supreme Court dissallowed the mere encouragement to be "race conscious." A case that expresses that view as well as any other case was Anderson v. Martin, ${ }^{44}$ decided succinctly and unanimously in $1964 .{ }^{45}$ The case involved a state statute that facilitated voter information respecting the racial identification of each candidate for local public office-by designating each candidate's race on each ballot, accurately and truthfully. Voters who might think that datum germane (as a white person to vote white, a black to vote black, a white to vote black, a black to vote white-as each might see a different, but steadfast significance in the idea) could hardly be kept from using it even in the absence of such specific ballot information. As the ballot designation by state law was nonetheless

${ }^{39}$ Hughes v. Superior Court, 339 U.S. 460 (1950). The earlier California case establishing the policy of nondiscrimination was James v. Marinship Corp., 25 Cal. 2d 721, 155 P.2d 329 (1944), recently extended and applied in Gay Law Students Ass'n v. Pacific Tel. \& Tel. Co., 24 Cal. 3d 458, 480-85, 595 P.2d 592, 606-09, 156 Cal. Rptr. 14, 28-31 (1979).

to Hughes v. Superior Court, 32 Cal. 2d 850, 856, 198 P.2d 885, 889 (1948), aff'd, 339 U.S. 460 (1950).

$4 I d$.

42 Id.

${ }^{43}$ Hughes v. Superior Court, 339 U.S. 460 (1950).

4375 U.S. 399 (1964).

15 Compare id. with United Jewish Orgs. v. Carey, 430 U.S. 144 (1977) (redistricting to favor Hispanics held permissible). 
thought objectionable, it could not have been because any candidate was exempt from it, since all were equally subject to it. It must have been, rather, that each was being individually disadvantaged insofar as the state thought it appropriate to encourage voters to attribute at least some significance to every candidate's race-and that the morality of the Civil War amendments was opposed to the very idea of such encouragement. And this, indeed, was the foundation of the decision in Anderson v. Martin: not that a black candidate in particular might be victimized insofar as the state's "truth in candidacy" statute would gratuitously stimulate white bloc votes, but that the state could not thus encourage such racial disadvantaging of anyone, white or black.

[B]y placing a racial label on a candidate at the most crucial stage in the electoral process-the instant before the vote is cast-the State furnishes a vehicle by. which racial prejudice may be so aroused as to operate against one group because of race and for another. This is true because by directing the citizen's attention to the single consideration of race or color, the State indicates that a candidate's race or color is an important-perhaps paramount-consideration in the citizen's choice, which may decisively influence the citizen to cast his ballot along racial lines. Hence in a State or voting district where Negroes predominate, that race is likely to be favored by a racial designation on the ballot, while in those communities where other races are in the majority, they may be preferred. The vice lies not in the resulting injury but in the placing of the power of the State behind a racial classification that induces racial prejudice at the polls.

...We see no relevance in the State's pointing up the race of the candidate as bearing upon his qualifications for office. ${ }^{46}$

Race has "no relevance"? That could not have been the Court's literal understanding, as the Court knew that vast numbers of people regarded the race of political candidates as being not merely "relevant" but conclusive. Rather, its meaning was that race has "no proper relevance" for the state. The connection with the original Harlan dissent in Plessy v. Ferguson seems self-evident: "[T]he Constitution of the United States," he had declared, "does not, I think, permit any public authority to know the race of those entitled 
to be protected in the enjoyment [of civil rights, common to all citizens]."47 The state may neither use race in its own business nor may it encourage others to take it into account. Both are equally divisive and equally wrong.

Following almost at once on Anderson $v$. Martin, moreover, the Supreme Court had cemented its judgment that the fourteenth amendment foreclosed government from encouraging-much less compelling-individuals to treat some better than they treated others because of race. It did so in Reitman $v$. Mulkey. ${ }^{48}$ In that case, the Court struck down a provision in a state constitution establishing the absolute right of each real property owner to sell or lease his property as he might personally, "in his own absolute discretion," ${ }_{49}$ choose. As thus enshrined in the California Constitution, the personal right to consider the race of others was equally as available to a developer preferentially selling or leasing to blacks as to a developer preferentially selling or leasing to whites. It was equally available as well to one desiring to use race to develop and to maintain an integrated racial balance in a given group of apartments. It was also available to black owners who wished not to deal with whites at all but who were resolved to reserve disposition of their property for persons of other races whom they might think to be more deserving-as it was available for every other imaginable permutation of racial dealing. But the strict indifference of the state constitutional privilege-its perfect governmental "neutrality" toward all racially predisposed private landowners-failed to save it under the fourteenth amendment. Rather, the California and United States Supreme Courts both held it to be a constitutional wrong for a state to encourage persons to act on racial grounds at all:

The right to discriminate is now one of the basic policies of the State. The California Supreme Court believes that the section [of the state constitution guaranteeing that right] will significantly encourage and involve the State in private discriminations. We have been presented with no persuasive considerations indicating that these judgments should be overturned.50

In this twenty-year pattern of development, from 1954 to 1974 , the Supreme Court's unambiguous "lesson" thus seemed to be that

\footnotetext{
17 Plessy v. Ferguson, 163 U.S. 537, 554 (1896) (Harlan, J., dissenting) (emphasis added).

4387 U.S. 369 (1967).

- Cal. Const. art. I, $\$ 26$ (adopted 1964, repealed 1974).

so 387 U.S. at 381.
} 
race was indeed constitutionally withdrawn from the incorrigible temptations of governmental use. The commitment was sufficiently strong, moreover, that the Court departed from its usual practice and struck down even surreptitious attempts by government to regulate or to allocate by race-though of course only when it was within the capacity of the judiciary to detect the matter. ${ }^{51}$ The resolve to do so, despite the obvious difficulties, was a very old one. Even prior to Plessy v. Ferguson, furtive efforts by government to employ race impermissibly had been overturned by the Supreme Court. ${ }^{32}$ The Court had readily recognized that any "irrebuttable presumption" of legislative good faith in these matters would be a disaster: the proclivity for race favoritism is so persistent that, unless the Court examined outside evidence that that proclivity did in fact account for the government's actions, the government would be encouraged to pursue its racial preferences in simple disguise. Thus, the Civil War amendments were held to nullify "sophisticated as well as simple-minded modes of discrimination." quence, if the metes and bounds of a municipal boundary were modified to enact the legislature's racial preferences, they would not stand. ${ }^{54}$ And if ostensibly appropriate government employment standards could be shown to have been adopted because their application across-the-board would screen out larger numbers of racially identifiable persons than the lawmakers desired to have from that race in their work force, the employment standard would be expunged. ${ }^{35}$

st The awkwardness of this judicial superintendence is plainly very great. See Ely, Legislative and Administrative Motivation in Constitutional Law, 79 YALE L.J. 1205 (1970). The ascertainability of racial purpose in legislative proceedings is much more elusive than in adjudicative proceedings. An employer or administrative agent may be closely examined in court with some realistic hope of determining whether a decision that has on its face nothing to do with race was made because it was expected (and desired) to produce differential effects by race. But members of Congress are shielded by the speech and debate clause, U.S. ConsT. art. I, $\$ 6, \mathrm{cl} .1$, from any such examination, and ordinarily it is impractical to attempt to secure confrontation in court of other legislators. For the most recent case illustrating the protective scope of the clause, see United States v. Helstoski, 99 S. Ct. 2432 (1979). Indeed, for one brief moment the Court appeared to despair of permitting evidence to be admitted for the purpose of establishing that a legislative decision, nonracial on its face, was nonetheless taken precisely because it would produce racially differential effects. See Palmer v. Thompson, 403 U.S. 217, 224-26 (1971). See also United States v. O'Brien, 391 U.S. 367, 38286 (1968).

32 E.g., Yick Wo v. Hopkins, 118 U.S. 356 (1886).

ss Lane v. Wilson, 307 U.S. 268, 275 (1939).

st Gomillion v. Lightfoot, 364 U.S. 339 (1960).

ss Washington v. Davis, 426 U.S. 229, 239-44 (1976) (dictum). Cf. Village of Arlington Heights v. Metropolitan Hous. Dev. Corp., 429 U.S. 252, 264-68 (1977) (zoning for the purpose of discriminating against blacks forbidden). 
Thus the lesson of the great decisions is, as Bickel said, not merely that regulation and allocation by race are wrong. Rather, the message is commendably even stronger. Laws that divide and index people to measure their civil rights by race are unconstitutional. Laws that encourage others to do so are similarly invalid. And laws attempting to advance either policy even in disguise will likewise be struck down whenever it is within the capacity of conscientious courts to see beneath their cellophane wrappers. ${ }^{56}$

\section{Of Teleology and Deontology in Constitutional Law: Flimflaming THE SuPreme CoURT}

Now this is to be unlearned and we are told that this is not a matter of fundamental principle but only a matter of whose ox is gored. Those for whom racial equality was demanded are to be more equal than others. Having found support in the Constitution for equality, they now claim support for inequality under the same Constitution.

Alexander M. Bickel ${ }^{57}$

If discrimination based on race is constitutionally permissible when those who hold the reins can come up with "compelling" reasons to justify it, then constitutional guarantees acquire an accordionlike quality.

Justice William O. Douglas ${ }^{58}$

It seems trite but necessary to say that . . . our Constitution was designed to avoid these ends by avoiding these beginnings.

Justice Robert H. Jackson ${ }^{59}$

At the time of Plessy v. Ferguson, the question before the Supreme Court in school segregation cases was whether state statutes requiring racially separate schools were constitutionally impermissible. For Justice Harlan, as we-have seen, the question was easily

ss The phrase is derived from the uncharacteristically aggressive dissent by eTustice Frankfurter in United States v. Kahriger, 345 U.S. 22, 38 (1953) (Frankfurter, J., dissenting).

${ }^{57}$ A. Bickel, supra note 12 , at 133.

ss DeFunis v. Odegaard, 416 U.S. 312, 343 (1974) (Douglas, J., dissenting).

39 West Virginia State Bd. of Educ. v. Barnette, 319 U.S. 624, 641 (1943). While Barnette was a freedom of expression case, the principle enunciated by Justice Jackson seems applicable in this context as well. See id. at 638:

The very purpose of a Bill of Rights was to withdraw certain subjects from the vicissitudes of political controversy, to place them beyond the reach of majorities and officials and to establish them as legal principles to be applied by the courts. . . . [T] 
answered. He insisted that the Civil War amendments had removed the race line as a basis of governmental action, and as the arrangement at issue-segregation-indubitably rested on the race line, it was constitutionally condemned. For the other Justices, however, as we have also seen, the question was by no means as readily answered. They did not suppose that the Civil War amendments had removed the race line as a predicate for governmental regulation or allocation; they asked, rather, whether the particular use of the race line was "reasonable." And, as we know, they concluded that it was.

Others, troubled by the frequency with which race lines were used deleteriously, have thought that the proper perspective is somewhere in between. ${ }^{00}$ They would construe the Civil War amendments as evincing at least a rebuttable constitutional skepticism about the use of racial classifications. Thus, it has been suggested that the appropriate judicial attitude is one similar to that assumed with respect to prior restraints on speech:11 laws utilizing the race line should be subject to a rebuttable presumption of unconstitutionality and nothing less than a compelling, or at least a very substantial, articulated public purpose should suffice to sustain them..$^{62}$ Despite Alexander Bickel's own notions respecting the lesson of the "great decisions," most who work with this subject think that, in fact, this is a more accurate description of the Supreme Court's current position. ${ }^{83}$

Suppose, however, we were to assume that this very formulation had itself been established and popularized prior to the date of Plessy v. Ferguson. ${ }^{64}$ In that event, given the formulation of the

1 There is, however, very considerable disagreement respecting the proper perspective on "in between." See authorities cited note 11 supra.

" E.g., Bantam Books, Inc. v. Sullivan, 372 U.S. 58, 70 (1963) ("Any system of prior restraints of expression comes to this Court bearing a heavy presumption against its constitutional validity."). The utility of the comparison is reviewed in O'Fallon, supra note 19, at 44-46.

"2 See authorities cited note 11 supra. The "test" dates from Korematsu v. United States, 323 U.S. 214, 216 (1944). It is full of irony. The Court, having erected this "protective" test, proceeded to apply it to the facts of the case and concluded that it was satisfied; in other words, the government met its burden of extraordinary justification. It turned out, however, that the government was pathetically mistaken in what it did. See E. Rostow, The Japanese American Cases-A Disaster, in ThE Sovereign Prerogative 193 (1962). Korematsu is significant additionally: it is the last case to sustain an explicit governmental race regulation as applied to the facts. It is now thirty-five years later and the "test" has not appreciated in value with the passage of time.

is See authorities cited note 11 supra. See also Regents of the Univ. of Cal. v. Bakke, 438 U.S. 265, $269-320$ (1978) (Powell, J.); id. at 324-79 (Brennan, White, Marshall \& Blackmun, JJ., concurring in the judgment in part and dissenting in part); Posner, The Bakke Case and the Future of "Affirmative Action," supra note 11, at 173-74.

" The discussion in this section is a more developed statement of views touched on in 
question presented above, what would the Court's decision have been in our hypothetical Plessy v. Ferguson school case? Two approaches are possible. The first would interpret the Civil War amendments as requiring that laws using race lines not only be well connected to substantial (or even "compelling") public purposes, but that such purposes themselves be "articulated" on the face of the law in question. ${ }^{65}$ Unless the legislature providing for racially separate schools declared such a purpose, then, the law must, a fortiori, be held invalid. But if, on the other hand, an articulated purpose is not required, then we are not yet in a position to determine whether the law using a race line overcomes the rebuttable presumption of unconstitutionality. Assuming that such a law must indeed be well connected to some very substantial public purpose, albeit the purpose need not be stated on the face of the law, it remains to be seen whether those called upon to explain the law will carry their burden of justification in court. If, but only if, the particular race line can be shown by them to be well connected with a very substantial public purpose is it to be sustained.

Under either view-that the law must on its face articulate the compelling public good it serves, or that those with the burden of justifying it must demonstrate its well-fitted connection with such an imperative public good-we may suspect that we already know the outcome of Plessy $v$. Ferguson: namely, that the law will most certainly be held invalid. But this conclusion may be incorrect; we must have supposed that no compelling public good can be well connected with such a law. Alternatively, we must have supposed that even if such a public purpose could (as an exercise in theory or imagination) be so connected, nevertheless it was not in fact connected with that law. Neither is necessarily correct. To act categori-

\footnotetext{
Van Alstyne, supra note 9, at 292-94, and Controversy: More on the Bakke Decision, supra note 9 , at 57-59.

65 It is not quite clear from some suggesting this test whether the suitably justifying purpose(s) must be "articulated" on the face of the law, or whether a subsequent, credible "articulation" in court will do; for the moment, it is evidently the latter. See, e.g., Regents of the Univ, of Cal. v. Bakke, 438 U.S. 265, 361-62 (1978) (Brennan, White, Marshall \& Blackmun, JJ., concurring in the judgment in part and dissenting in part); Hampton v. Mow Sun Wong, 426 U.S. 88, 103 (1976) ("When the Federal Government asserts an overriding national interest as justification for a discriminatory rule which would violate the Equal Protection Clause if adopted by a State, due process requires that there be a legitimate basis for presuming that the rule was actually intended to serve that interest."). See also Califano v. Goldfarb, 430 U.S. 199, 223 n.9 (1977) (Stevens, J., concurring in the judgment); Craig v. Boren, 429 U.S. 190, 199 n.7 (1976). For a discussion of why this should influence the standard of judicial review, see Christie, A Model of Judicial Review of Legislation, 48 S. CAL. L. REv. 1306 (1975).
} 
cally on such suppositions is not to abide by the constitutional standard hypothetically formulated and popularized. Rather, it is to act on a flat, per se rule, albeit of a rather limited kind, that "no law requiring racially separate schools is constitutional." But this, of course, our more sensitive, less dogmatic, and more judicious standard of constitutional review forbids-although, in fact, it is exactly what the Supreme Court did in virtually all of the postBrown per curiam decisions invalidating "separate-but-equal" laws. Our commitment to the flexible standard requires that we consider the matter further.

If the standard required that a very substantial public purpose appear on the face of the law itself, we concluded in the first instance that this law would have failed because the statute in question contained no such recitation. Yet, if that standard of judicial review were already well established and popularized at the time, we may expect that legislatures, advised of it, would explicitly state their purpose. Suppose, then, that this had been done. Is the law now constitutional, or is it unconstitutional? The question cannot be answered, of course, until we turn to see what the legislature said.

Suppose, then, that the statute had required racially separated schools and had further provided that this requirement was enacted "in order to perpetuate white supremacy and to degrade black people"- the purpose many declare was, in fact, at the root of all such laws. ${ }^{86}$ In that event, of course the law will fail. Indeed, the Justices in the majority in Plessy $v$. Ferguson declared that had such a purpose been established in that case, that law too would have failed: "every exercise of the police power must be reasonable, and extend only to such laws as are enacted in good faith for the promotion for the public good, and not for the annoyance or oppression of a particular class." 67 And they rejected the attack on the law in question as being insufficient because it rested on "the assumption that the enforced separation of the two races stamps the colored race with a badge of inferiority," rather than in proof that such a stigma was intended. ${ }^{88}$

But given the established and popularized constitutional "standard" such legislation must meet-a well-connected substan-

" E.g., Black, The Lawfulness of the Segregation Decisions, 69 Yale L.J. 421 (1960).

17 Plessy v. Ferguson, 163 U.S. 537, 550 (1896) (emphasis added).

4 Id. at 551 (emphasis added). See also Black, supra note 66; Cahn, Jurisprudence, 1955 Annual Survey of American Law, 31 N.Y.U.L. Rkv. 182 (1956); Cahn, Jurisprudence, 1954 Annual Survey of American Law, 30 N.Y.U.L. Rev. 150, 153-54, 157-68 (1955); Pollak, Racial Discrimination and Judicial Integrity: A Reply to Professor Wechsler, 108 U. PA. L. Rzv. 1, 24-31 (1959). 
tial public good articulated on the face of the law-it is unrealistic to suppose that the legislature enacting this law would have so declared itself, regardless of its actual motives. At least it is safe to suppose that no other legislature, observing the fate of this legislature's bill, would repeat the original error. Suppose, then, the face of the law articulated the very different purpose that fully equal but racially separated schools were to be established "in order to assure a historically disadvantaged racial minority an equal opportunity to develop educational curricula and programs more responsive to their needs, free from domination in schools in which their children might otherwise be overwhelmed by a racial majority." The "public good" is surely impressive, the expression of social contrition is moving, and the linkage between the compelling purpose of this law and the means chosen to advance it seems suitably tight. Is the law now to be upheld? Presumably it is, unless one suspects that the recitation is a fraud-that the recitation is for the benefit of anchoring its constitutionality, while the law is actually meant to perpetu. ate white supremacy.

One may suppose that if there is fraud here, it will easily be penetrated. But that assumption is remarkably cavalier. The Supreme Court has utilized "purpose" as one prop in its "test" in its administration of the religious establishment clause of the first amendment ${ }^{68}$-and since the inauguration of that test virtually no law has been held invalid for failure to meet the "purpose" part of the Court's own chosen test. ${ }^{70}$ Even when few have doubted that the legislation in question was the product of sectarian self-interest, which the reigning "test" declares to be an improper purpose under the first amendment, recitations emphasizing other effects"permitted" effects-have been taken as virtually conclusive in meeting the ostensible constitutional command that such laws

"U.S. CoNsT. amend. I. The "test" was enunciated in School Dist. v. Schempp, 374 U.S. 203, 222 (1963) ("[W]hat are the purpose and primary effect of the enactment? If either is the advancement or inhibition of religion then the enactment exceeds the scope of legislative power as circumscribed by the Constitution.") (emphasis added). For an illustrative "application," see Board of Educ. v. Allen, 392 U.S. 236 (1968). See also id. at 254-66 (Douglas, J., dissenting); Note, Sectarian Books, the Supreme Court and the Establishment Clause, 79 YALE L.J. 111 (1969). Note also how the "purpose" part of the test was not applied in Lemon v. Kurtzman, 403 U.S. 602 (1971), and how mere legislative declaration of "purpose" effectively insulated statutes from meaningful review as to this part of the test in Wolman v. Walter, 433 U.S. 229 (1977); Roemer v. Board of Pub. Works, 426 U.S. 736 (1976); Committee for Pub. Educ. \& Religious Liberty v. Nyquist, 413 U.S. 756 (1973); Tilton v. Richardson, 403 U.S. 672 (1971). See generally P. KuRland, Religion and the Law of ChuRch and State AND THE SUPREMe CoURT (1962).

70 See discussion and cases cited note 69 supra. 
have secular objectives as well as primary nonreligious effects. There is no reason to expect a different result here.

In the previous section of this article, we noted that under the constitutional standard that seems to have emerged during the past quarter century, ${ }^{71}$ a law will not be sustained under any of the following three circumstances:

(a) if it overtly utilizes race as an index for determining civil rights;

(b) if it expressly encourages others to do so; or

(c) if it tends to produce either of these effects and if the expectation of that tendency can be shown to account for the law's enactment even when the law, on its face, says nothing whatever about race.

This judicial resolve to remove the race line from our public life has been the most credible and admirable position for the Court steadfastly to maintain, so far as we are under a Constitution and so far as that Constitution is what the judges say it is. But under the more flexible "test"-which allows allocation by race when certain criteria are met-to strike down a statute it is not enough to show that the law itself explicitly treats the rights of one person differently from those of any other by making race itself a sufficient reason for that difference. Rather, one must also "decide," even in every case arising in each of the above categories, two additional matters:

(1) what kinds of public purposes are sufficiently compelling to justify explicitly treating some people less well than others on racial grounds; and

(2) who is to say (and on what basis) that a law, which on its face is nominally very well connected with a sufficient public purpose, making its purposive racial discrimination "justifiable" under (1), was indeed enacted solely to promote that objective rather than to enact some baser interest with which it is equally well connected?

This is not, I think, a constitutional standard at all. It is, rather, a sieve-a sieve that encourages renewed race-based laws, racial discrimination, racial competition, racial spoils systems, and mere judicial sport. It is Plessy v. Ferguson all over again, in new and modish dress. In the revised Plessy case we have just been considering-facially rationalizing racially segregated schools for contrite, moral, and "minority-favoring" purposes-we have not yet 
noticed anything about the geographic, demographic, or political context in which the law appeared. Are such considerations germane, or are they to be ignored? Most plainly they must be treated as highly germane, ${ }^{72}$ for otherwise our "test" becomes a farce and some atrocious uses of the race line will be sustained by our courts-as I suppose we would agree would be the case if the school segregation statute, with its pious accompanying recitation, were the product of an all-white southern state legislature circa 1900. But as a different possibility, suppose that the law were not one from a state legislature at all, but rather one promulgated by a city board of education-in a predominantly black school district with a majority of the school board members themselves black? Is this, too, to make some difference? What difference shall it be ${ }^{73}$

If it could be shown that the purpose was not as declared, but was rather to "degrade" black people, the statute must fall. Suppose, however, that it was a product of some of each purpose, so that some members of the state legislature supported it in fact and in good faith on the very grounds recited in the law, while others were pleased to go along because they simply wanted to separate black children from white children. Or, suppose that the "purpose" was nothing more sublime than the preoccupation of each legislator to retain his own elected position by voting for whatever measure seems most pleasing to the largest or most influential bloc of his constituents, some of whom, both black and white, favor this law (albeit not necessarily for identical reasons), some of whom oppose it (albeit for differing reasons as well).

All of these questions will recur, of course, even if it is not constitutionally required that the "substantial" or "compelling" public interest allegedly served by such race-line laws be recited on the face of the laws themselves. Indeed, assuming no such additional requirement, we may expect such recitations to appear anyway, insofar as they may be regarded by the Court as prima facie evidence of the law's actual purpose..$^{74}$ All this, and much more, awaits the Supreme Court once it leaves the lesson of the "great decisions" of the past twenty years and, indeed, the lesson not just of "contemporary" history, but of our whole history.

${ }^{2}$ Cf. Ély, supra note 11 , at 723 (arguing that majority discrimination against itself is per se legitimate). But see Posner, The DeFunis Case and the Constitutionality of Preferential Treatment of Racial Minorities, supra note 11, at 19-26.

${ }^{73}$ For one view, see Bell, Waiting on the Promise of Brown, 39 Law \& Contemp. Prob. $341,360-63$ (1975).

iu Exactly as did happen once this type of test was publicized for the first amendment's establishment clause. See cases cited note 69 supra. 
I have used in this particular exercise of flimflamming the $\mathrm{Su}-$ preme Court variations on Plessy v. Ferguson. It is not necessary, however, to be so wholly hypothetical. An actual example was well provided last year in Regents of the University of California $v$. Bakke. ${ }^{75}$ The Regents' Supreme Court brief treated the case as though the use of race itself to establish separate and unequal admission standards at the Davis medical school were really not the issue. Rather, the issue was better to be seen as a revised, updated version of Plessy $v$. Ferguson: that it is not the use of race as a means of assigning students to different schools that is at issue, but the reason for making such assignments. Thus, the question as set forth in the Regents' brief in Bakke was framed in the following selfcongratulating and self-validating fashion:

When only a small fraction of thousands of applicants can be admitted, does the Equal Protection Clause forbid a state university professional school from voluntarily seeking to counteract effects of generations of pervasive discrimination against discrete and insular minorities by establishing a limited special admissions program that increases opportunities for wellqualified members of such racial and ethnic minorities?76

There was no impropriety in this framing of the question given the fact that even long after Plessy and notwithstanding Brown, dicta in Supreme Court decisions continued to encourage racial discrimination by government-that which might overcome a merely rebuttable presumption of unconstitutionality by being well connected with "compelling" public purposes. ${ }^{77}$ Indeed, the joint opinion by Justice Brennan (writing for himself and for Justices White, Marshall and Blackmun) fulfilled those dicta in its treatment of the Bakke case itself.

After acknowledging that the effect of the equal protection clause is at least to reverse the usual presumption of constitution-

73438 U.S. 265 (1978).

7 Brief for Petitioner at 2. Four members of the Court (Burger, Stewart, Rehnquist \& Stevens) found it unnecessary to consider this question. It was plain to them that the use of racially separate and unequal admissions standards was forbidden by Title VI of the Civil Rights Act of 1964, 42 U.S.C. $\$ 2000$ d (1976); they therefore applied Title VI as forbidding any kind of racial discrimination and voted to affirm the California Supreme Court, which had held for Bakke on constitutional grounds, 438 U.S. at 408-21 (Stevens, J., joined by Burger, C.J., and Stewart and Rehnquist, JJ., concurring in the judgment in part and dissenting in part). Insofar as granting relief to Bakke was concerned, their votes were joined by that of Justice Powell. Id. at 271 (Powell, J.).

7 For a discussion of how the presumption of unconstitutionality works in the analogous first amendment context, see text at note 61 supra. 
ality in instances where government presumed to regulate or to allocate by race, that joint opinion then went forward to explain how such actions might nonetheless be sustained. First, "an important and articulated purpose for its use must be shown."78 "In addition," the opinion continued, "any statute must be stricken that stigmatizes any group or that singles out those least well represented in the political process to bear the brunt of a benign program."78 If both of these "standards" are met-as they were met according to these four Justices in Bakke-then even separate and unequal ways of treating people by race are wholly constitutional. Given this kind of invitation to "accentuate the positive" benefits of racial discrimination, the Regents' attorneys would have been professionally derelict not to have rushed right in.

Yet there are obvious difficulties with the revised proposed "test." If a $16 \%$ additional ${ }^{80}$ racial set-aside can be provided because it "counteracts" effects of "discrimination" by increasing "opportunities" for "well-qualified members of such racial and ethnic minorities," there is no reason to think that the good to be accomplished is less impressive or that the connection with the plan would be less snug though the additional set-aside were $20 \%, 50 \%$, $60 \%$, or whatever; neither should it make any difference whether it were keyed to California population statistics, local population statistics, national population statistics, or world population statistics. If the ends are sufficient and the means well connected, moreover, surely it ought make no difference that the plan was adopted by a predominantly black city council-approving a self-favoring racebased additional set-aside for municipal employees-rather than adopted by a predominantly white medical faculty at a state university. ${ }^{81}$ Insofar as the racial complexion of the government unit is seen as furnishing some probative evidence as to the "real" purpose of the plan, surely it would be objected that it is the worst sort of racism to suppose that a plan inaugurated by a predominantly black elected body is more suspect than an identical plan inaugu-

73438 U.S. at 361 (Brennan, White, Marshall \& Blackmun, JJ., concurring in the judgment in part and dissenting in part).

nId. (emphasis added). As to whether the Davis plan may have imposed such a stigma, see note 38 supra.

${ }^{80}$ Fourteen percent of the total regular admittees for the two years in which Bakke was rejected were of the minority groups favored additionally by the $16 \%$ racial set-aside. See 438 U.S. at 276 n.6 (Powell, J.).

${ }^{31}$ See also Craig v. Alabama State Univ., 451 F. Supp. 1207 (M.D. Ala. 1978); Detroit Police Officers Ass'n v. Young, 446 F. Supp. 979 (E.D. Mich. 1978); Ely, supra note 11. But see text at note 72 supra. 
rated by a predominantly white one. Indeed, as we have already seen, there is no reason in any case to suppose that whatever the "recited" purpose of the plan may be, that such purpose bears any necessary correspondence at all to the dominant political factors actually accounting for its adoption. The Bakke case is itself quite sufficient to display all of these difficulties, with no need to do much more than to notice the facts and match them against the "requirements" of the joint opinion's test pursuant to which separate and unequal standards are constitutionally approved for persons identified by race.

The plan involved in the Bakke case was approved by a predominantly white faculty. The "brunt" of the plan was borne by individuals like Allan Bakke-white applicants with reasonably good application portfolios, but not among the very best portfolios. White applicants with the very best portfolios would of course be unaffected by the plan, as the faculty perfectly well knew. ${ }^{82}$ Were persons in Allan Bakke's position thus well represented in "the political process" that singled them out to bear the brunt of the program? Four Justices evidently believed they were, as their opinion says that that kind of representation must be present in order for such a plan to be upheld, even when the plan otherwise meets their proposed constitutional standards. But on what conceivable basis could such an assumption be made? Just because Bakke was white-as were the majority of the medical school faculty? But the majority of the medical school faculty were themselves not likely to have been "representatives" of the Allan Bakkes, that is, reasonably good, but not among the best medical school applicants. If we should assume anything about that faculty -as the four Justices acted wholly upon unexamined assumptions of political and sociological stereotypes-we might more safely assume that the faculty "represented" not persons in Bakke's position at all but only outstanding students, persons who do especially well in academic life, who do equally well through medical school, and who are thus sufficiently outstanding to have been

32 Insofar as the faculty withdrew 16 seats from the original freshman-class total of 100 (reducing the number of openings to be filled by the regular admissions process to 84 and restricting eligibility for the 16 seats exclusively to disadvantaged nonwhites), the faculty certainly understood that applicants who would otherwise have been admitted pursuant to the regular admissions process but who would now be displaced would be white applicants with good-but not the best-portfolios. The "best" white applicants would be unaffected, as they would still be among the 84 best applicants within the regular admissions process. 
granted academic appointments in a great university. We might also assume that their concerns are not likely to place them in natural empathy with an Allan Bakke in any other sense either-that their interest, in a highly civil rights sensitive university campus and atmosphere, is to be counted as being "racially sensitive" people.

Given these very troubling facts, then those who bore the brunt of the Davis program were not only not well represented in the political process that singled them out for its burdens-they were, rather, among "those least well represented." Yet this, the opinion of the four Justices declared, would be sufficient reason, entirely by itself, to regard the plan as constitutionally defective. Still, they failed to do so.

The plain point of all this will not, one trusts, be mistaken as an attack on the Davis medical school faculty. The point, rather, is that even as applied by those members of the Court most beguiled by the Lorelei of "right" racial uses by government, their own proposed standards of judicial supervision are not applied ${ }^{83}$ and, in any serious fashion, are manifestly incapable of any useful applications. These "standards" will, rather, quickly reduce themselves to empty recitations that serve only to put the Supreme Court's own endorsement on new racial systems-many of which will doubtless be the spoils systems of pure racial politics-inviting persons again to "think racially," to "vote racially," and to band together in racial blocs as much from necessity as from any choice of their own.

In brief, this is the "accordionlike quality" of a Constitution construed to permit racial discrimination "when those who hold the reins can come up with 'compelling' reasons to justify it," anticipated and rejected by Justice Douglas..$^{84}$ Most certainly there is no feasible way of forestalling such consequences under the porous "standard" now beckoning the Supreme Court to its third rite of passage. Rather, as Justice Jackson declared in another context, "[i]t seems trite but necessary to say that . . . our Constitution was designed to avoid these ends by avoiding these beginnings." 85 And the only secure way to do that is to abide by the "lesson of the great decisions of the Supreme Court and the lesson of contemporary history. . . : discrimination on the basis of race is illegal, im-

For a recent case extending Bakke's rationale to sustain discriminatory race and sex standards in the hiring, promotion, transfer, training, and work assignments of public employees, see Minnick v. California Dept. of Corrections, 95 Cal. App. 3d 506, 157 Cal. Rptr. 260 (1979).

34 DeFunis v. Odegaard, 416 U.S. 312, 343 (1974) (Douglas, J., dissenting).

s West Virginia State Bd. of Educ. v. Barnette, 319 U.S. 624, 641 (1943). 
moral, unconstitutional, inherently wrong, and destructive of democratic society." 88

\section{The Next Term of Court}

When Alexander Bickel expressed his point, insisting on what he described as the lesson of the great decisions, it was a most uncharacteristic utterance. To be sure, Bickel had clerked on the Court during Brown v. Board of Education and had published an extremely compelling article in defense of that decision. ${ }^{87}$ Yet, Alexander Bickel was far better known as a scholarly exponent of judicial restraint, an advocate of judicial conservatism. Not for him were there many "fundamental" truths that the Supreme Court should apply. Rather, "balancing" was the usual best course for the Court, and the Court ought not lightly overturn the action of a legislature. ${ }^{88}$

As this was so, a fair question is raised about Bickel's seeming inflexibility in the particular instance of explicitly racial laws. Quite plainly he did not think that to get "beyond" racism, it is useful or helpful first to undertake a new generation of racially discriminatory laws. ${ }^{80}$ But apparently others believe that it is, and surely their beliefs are entitled to some weight. When their view is reflected in an act of government, moreover, ought it not be counted heavily in some "balance," deferred to unless manifestly irrational-or unless, though rational, somehow simply not relevant to the constitutionality of the practice? There is no obvious accounting for the exceptional rigor of Bickel's commitment to a firm, unwavering, single constitutional standard on this subject. There is, however, an obvious practical reason why the usual virtues of judicial conservatism could be extremely ill-served by anything other than a very consistent, very firm position that leaves nothing to further misunderstanding.

We have had three hundred years of national experience to notice that whenever race has been an admissible criterion of governmental action, its licitness left people in public office without shelter against the organized efforts of those who would demand that they have a duty to act on that licitness: that they carry the

s A. Bickri, supra note 12, at 133.

Bickel, supra note 7.

88 See, e.g., A. Bicked, The Supreme Court and the Idea of Progress (1970); A. Bickrt, The Least Dangerous Branch (1962); Bickel, The Supreme Court, 1960 Term-Foreword: The Passive Virtues, 75 Harv. L. REv, 40 (1961).

3 For the contrary view, see Regents of the Univ. of Cal. v. Bakke, 438 U.S. 265, 407 (1978) (Blackmun, J., opinion of). 
alleged "merits" of race into appropriate legislation. We are also not without example of the inevitable necessity, the instant such regulation or allocation by race has been understood to be acceptable to the Supreme Court, for the Court ultimately to have to decide several other things as well. Among the more obvious issues, as additional groups, people, agencies, and parties are inevitably drawn in, are these: which races, how much to each race, by what test is each of us to be assigned "our" race? When these things were proper-as they were before Brown v. Board of Education-it was enough to be the government-designated member of a given "race" by being oneeighth of that "race." That, as the Supreme Court itself will recall, was the manner of imputing "race" to Mr. Plessy for the Plessy $v$. Ferguson experiments in racial designation and racial allocation. ${ }^{90}$ The odiousness of these issues will be no less should the Court now reopen this governmental license than it was some years ago.

Should the government be upheld in its first unqualified efforts to revive its powers of regulation and allocation by race, in Fullilove $v$. Kreps, ${ }^{91}$ before the Court for its consideration this fall, moreover, we may expect to be afflicted with this way of life for the balance of the century. Most certainly, once the Court admits the government's basic practice, it will be without any defensible ground to halt that practice or to roll it back within our own lifetime. Neither can it, I think, find any way whatever to police the inevitable cynicism and race politics explicit in our common future once the basic issue is decided, as evidently it shall be within a year.

By a very casually adopted amendment added to a bill, "Congress" has provided for a $10 \%$ strictly racial set-aside for certain kinds of federal contracts, exempting firms with appropriate racial "certification" from competing with other firms, and guaranteeing the certified firms that they need only compete among themselves for this share of the national business. The constitutional wisdom of sustaining this statute has been discussed almost

"Plessy was deemed to be "colored" (in the words of the state statute) for purposes of assigning him to a given car, although he was "of seven eighths Caucasian and one eighth African blood; . . . [and] the mixture of colored blood was not discernible in him . ..." 163 U.S. at 538. The majority of the Court, once accepting the constitutionality of using the race line as a permissible way for legislatures to regulate and allocate, also recognized the sorts of decisions implicit in that determination: "The power to assign to a particular coach obviously implies the power to determine to which race the passenger belongs, as well as the power to determine who, under the laws of the particular State, is to be deemed a white, and who a colored person." Id. at 549. See also Posner, The Defunis Case and the Constitutionality of Preferential Treatment of Racial Minorities, supra note 11, at 12-14.

" 584 F.2d 600 (2d Cir. 1978), cert. granted, 99 S. Ct. 2403 (1979), briefly described in note 9 supra. 
entirely at an abstract level of compensatory jurisprudence. It has virtually left out of account entirely the more pedestrian realities. Once these inevitable realities are considered, it may not be in our common interest to urge the Supreme Court once more to pontiusly pilot its way through proposed heaps of federal, state, and local racial spoils systems, conferring the noblesse oblige of racial shares on the wretchedly shaky foundations of racial politics-deferring to "good faith" efforts, differing as they will (and as they already do) as to how big a share $(10 \%, 20 \%, 50 \%)$, what groups to qualify for their "share" (blacks, Hispanics, women, Indians, Orientals, Aleuts), who comes within each group (all Hispanics or merely those from certain places, all blacks, or merely those from families of less than $\$ 15,000$ annual income). There is not the slightest disrespect in confronting these matters in these terms, moreover, as they are the government's own way of confronting them, its way of governing. I find it very difficult to accept that serious students of constitutional law and of American history would truly desire the Supreme Court to approve these structures of government. I think Bickel understood all of this perfectly well and that that may be why, on this subject, for once he went to fundamentals and to absolutes.

The Washington Post of May 22, 1979, carries the following earnest report on the manner in which these matters run even now:

A highly unusual and controversial proposal under consideration by a city agency would eliminate a large number of local ethnic groups from eligibility for lucrative minority contracts with the District of Columbia government.

The proposal, by the staff of the Minority Business Opportunity Commission, would eliminate from minority status all Hispanics born in Europe and South and Central America, leaving only those Hispanics born in Mexico or Puerto Rico eligible for the contracts.

The proposal also would eliminate from minority status persons born in Vietnam, India, China, Korea and Africa.

Four major local Hispanic-owned companies have won a total of more than $\$ 20$ million worth of the city's minority contracts in the last year. This represents 40 percent of the entire minority share of the local market.

The recommendation requires the approval of the commission and Mayor Marion Barry. One commission member, Peter Taylor, said he supports the change.

"Lots of people here are coming in with bags of money from Vietnam and other places and buying up corporations," 
Taylor said. "They are . . . killing the little guy."

A commission staff member said the proposed shift in guidelines is part of an effort by the commission to increase the number of city contracts going to blacks and "disadvantaged minorities."

"We just want to make sure that [blacks] who were supposed to benefit get their fair share," the staff member said.

A staff member who helped draft the proposed guidelines said individual companies owned by minority applicants will be considered on their merits " [sic] whether or not [the company] was historically disadvantaged in the United States" before a final decision on certification is made. -

The proposed change is not without precedent in federal minority programs. Congress recently dropped Asian Americans from the federal Small Business Administration program for minority contracting.

"Oh, my God," one influential Hispanic leader with ties to the Barry administration said when informed of the staff proposal. "If Marion agrees to do something like that, then it's really going to be a political war between Hispanics and blacks, and that would be terrible."

Carlos Rosario, acting director of the Office of Latino Affairs for the District, said he was not familiar with the proposal. But, he said, "I don't see why if they have Spanish heritage why they should lose their [eligibility for minority contracts]. If they are born minorities, they should have the same breaks as others."

"I've been working in the District of Columbia for 20 years," said Jose Rodrigues, who was born in Argentina and is co-owner of a major Hispanic company that does minority business with the District. "To be Rodrigues or black is the same thing. If there is [a minority program] in this country for blacks, it should be for Spanish people."

Rodrigues and his brother Francisco own Fort Myer Construction Corp. in Arlington, which he said does more than $\$ 3$ million in minority business with the city. He said his business also does another $\$ 1.5$ million in the regular competitive market.

Angel Roubin, who was born in Spain, said: "It appears to me that if the city take that position, they are trying to discriminate against other minoriies [sic]." 
In support of the proposed change, Col. Milton Carey, president of Associated Minority Contractors of America, a District-based national organization representing primarily black contractors, said: "There are Spanish who have culturally lived as white persons all their lives and in recent years found it profitable to consider themlselves [sic] minority to take advantage of business in the minority community.

"They are bringing in superior resources to bear so they are more competitive in the sheltered market."

The key question, Carey said, is, "Have you been culturally disadvantaged in the United States. Have you been forced to live in a cultural bag? If the answer is yes, I say welcome."

The original guidelines are spelled out in a 1976 D.C. law that entitles local minorities to 25 percent of the city's contracting dollars. The law stipulates that minorities must be certified as such by the commission. Once certified, minorities only compete with minority firms when bidding on District contracts.

Commission staff members said the proposed changes in guidelines followed complaints by black contractors that many of those who were originally certified by the commission came from aristocratic classes of foreign countries.

Another staff member said, "We were being besieged by applicants from all over the world and we had to do something about it." 92

The fecundity of administrative regulation and of invidious choices, once race itself is reintroduced as an additional index of governmental action, are all present here in microcosm. The concrete example is the use of racially separate and racially unequal standards in the award of government contracts. It might just as well be racially separate and racially unequal employment standards, racially separate and racially unequal educational admissions standards, racially separate and racially unequal voting rights, tax credits, or some other: each contingent on race, racial authenticity to be ascertained and certified by government, with entirely earnest sorts of good faith controversy as to what one counts.

And so what, in all good faith, shall we say about these matters? Should it indeed be enough that one was born (distinguishably) into a "minority" race, or must one's race also have been "historically disadvantaged" as well? Is it insufficient that one be

"2 Thompson, City Agency Weighs Restricting Some Ethnics' Minority Status, Wash. Post, May 22, 1979, \& A, at 1, col. 1 (insertions in original). 
born of that race, however, unless people of that race were historically disadvantaged "in the United States" rather than merely in other places? If one qualifies by these standards, is he nonetheless to be disqualified from the reserved advantage of additional, racially designated shares if he is "Asian American," Vietnamese, Indian, Chinese, or Korean? Must one not merely be a certifiable member of one of the remaining "races," but also be born in the United States itself (so that being born in Africa, being born in Latin America, or being born in Spain will not count)? Yet, though not born in the continental United States, if one is "Hispanic" and is also born either in Mexico or in Puerto Rico (but not otherwise), may one compete not only with "Anglos" but, aside from one's business derived from that competition, have access to a special racial set-aside? In each instance, moreover, is the "appropriate" test of a company the determination of ownership of a majority of voting shares of the stock, or is it rather something else or something in addition (suppose the company is 51\% "black" owned, yet the executives and majority of the employees are "white")? The necessity to make and to police fine distinctions is clear enough. The necessary consequences of encouraging racial competition and racial resentments are all quite manifest ("Oh, my God, ... if [the mayor] agrees to . . . that, then it's really going to be a political war between Hispanics and blacks").

\section{CONCLUSION}

Nearly all who have urged the Supreme Court to readmit the legitimacy of race as an explicit basis of governmental regulation or allocation have done so with some reserve, some measure of diffidence, hedged about that, in any event, it should only be for a time..$^{93}$ But no means whatever have been forthcoming from this permissive jurisprudence to enable the Court, once it unlearns its own lesson of history, to avoid the resulting dilemma: either to attempt thereafter to superintend the products of the new learning with the considerable risk of being overwhelmed by the need to make distinctions so numerous and so rank as to find itself discredited, or to pronounce a benediction on the presumed rectitude of executive or administrative bodies, and the presumed superior capacity of legislative bodies to determine these matters, and retire from the field for another generation.

${ }^{13}$ E.g., Regents of the Univ. of Cal. v. Bakke, 438 U.S. 265, 403 (1978) (Blackmun, J., opinion of). 
It has been very tritely observed that the Constitution is a "living" document. The observation is nearly always offered as a prelude for urging the Supreme Court to manipulate or disregard some rather unequivocal part of that document. In this instance, however, there is nothing in the Constitution that licenses the national government to establish racial shares, to legitimate measuring the worth of people by their race, or to tender entitlements by race. Keeping faith with the lesson of the great decisions of the Supreme Court during the past three decades, moreover, requires no new, manipulative use of any provision whatever. Quite the opposite is true: the novelty is in the explication of arguments to relicense governmental discrimination. The basic question before the Court is whether the Constitution shall again be "adjusted" to accommodate a new generation of racial spoils.

There is, even as the District of Columbia program illustrates, very little agreement in measuring racial eligibility for those spoils. There being no serious prospect for such agreement, and the Constitution itself providing no articulate basis for the Court simply to "declare" the proper eligibility, the natural expectation is that that racial eligibility will simply be the product of racial competition in the political process. ${ }^{94}$ Incentives to make out cases of racial "mine" and "thine" are thus supplied, and doctrine is to be arranged in a fashion most calculated to stimulate race politics.

Ironically, the basic suggestion to relicense racial discrimination by government is put forward not despite its intrinsic tendency to set race against race, but as a good, benign, and thoughtful way to get beyond racism. But "getting beyond" racism in this fashion, we have reason to believe, is as little likely to succeed as the now discredited idea that in order to "get beyond" organized government, it is first indispensable to organize a virtual dictatorship that, once it extirpates the evils that made organized government necessary, will itself just naturally wither away. We have not seen governments wither by the paradox of assigning them even greater power. We shall not now see racism disappear by employing its own ways of classifying people and of measuring their rights.

Rather, one gets beyond racism by getting beyond it now: by a complete, resolute, and credible commitment never to tolerate in one's own life-or in the life or practices of one's government-the differential treatment of other human beings by race. Indeed, that

" See note 90 supra. See also the conclusions reached on the same subject in B. BrTTKER, supra note 11, at 104. 
is the great lesson for government itself to teach: in all we do in life, whatever we do in life, to treat any person less well than another or to favor any more than another for being black or white or brown or red, is wrong. Let that be our fundamental law and we shall have a Constitution universally worth expounding. 